\title{
Information Flow Management and the Effectiveness of the Supply Chain of Essential Medicines in the Public Sector. Evidence from Selected Public Hospitals in Uganda: A Downward Perspective
}

\author{
John Charles Okiria ${ }^{1,}$ R. Mwirumubi ${ }^{2}$, K.A Mpaata ${ }^{2}$ \\ ${ }^{1}$ School of Post Graduate Studies and Research Nkumba University Uganda
}

\begin{abstract}
This study assessed the relationship between the Information flow management in the public hospitals and the effectiveness of the downward supply chain of essential medicines in the selected 6 public hospitals in Uganda. A cross sectional descriptive and analytical survey was done with both qualitative and quantitative data collected. Two hospitals were regional referral and the four were general hospitals. The major findings of the study were that; sharing planning information, distribution schedules, knowledge of each other stock levels and new demand were statistically significant in influencing the downward supply chain effectiveness. Improved sharing of information that is accurate, timely and complete, development of computerized medicines management systems in the hospitals, Collaborative procurement planning at all levels, Improvement in records and record keeping and enhancement of online communication between the hospitals and the suppliers was significantly influencing the effectiveness of the supply chain
\end{abstract}

Keywords: Inventory, supply chain, Information flow, medicines, effectiveness

\section{Introduction}

Agarwal and Shankar (2002) described a supply chain as an interlinked set of relationships which connects customer to supplier. It involves a series of intermediate stages such as manufacturing, warehousing and distribution. Supply chain management (SCM) involves the management of product, information and financial flow from the source of supplies to the manufacture and assembly of the product right to the delivering of the final product to the consumer. It also includes the management of after sales service and the product returns (Lee, 2000). The objectives of SCM are to increase productivity, reduce inventory and cycle time but its ultimate goal is to increase customer satisfaction, market share, and profits for the entire supply chain in the long run (Wisner and Tan, 2005).

The information dimension encompasses the communication and decision making infrastructure which overlays and is interwoven with the physical dimension. With few exceptions (Jones, 1997), a literature search regarding the specific role of information within the Lean paradigm derives a low yield. However the pivotal role of information was identified during numerous Lean Enterprise Research Centre (LERC) research projects (James et al, 1996).

Information flow is an integral aspect of supply chain management (Lambert et al., 1998). The importance of information flow in supply chain was demonstrated by Singh (1996) who proposed that information must be managed at three different stages, before, during and after sales have been made.

Information sharing is essential as it provides the mechanism for coordination and integration of the processes or activities along the supply chain (Lee, 2000; Ramayah and Omar, 2010). Singh (1996) observed that in order to ensure that customer requirements in the supply chain can be fulfilled, it is fundamental to manage the information flow associated with the movement of products (goods or services) to the final customer. Effective flow of product and services is dependent on information sharing among supply chain members (Lee et al., 1997). Firms would be able to respond effectively to changing market demand requirement through information sharing (Mason-Jones and Towill, 1997).

According to (Bowersox et al., 2000; Gustin et al., 1995), information sharing among supply chain partners enables firms to achieve common goals besides enabling the coordination of the supply chain processes (Lee, 2000; Barratt, 2004; Lambert 2004). The level of information sharing across the supply chain can be influenced by the supply network configuration and goal congruence of the supply chain partners (Samaddar et al., 2006).

Information sharing is also particularly important within the internal supply chain. If firms cannot share information internally, it would be difficult to share information externally with their partners (Rupple, 2004). Information can have dual functions; it benefits the supply chain entities and it can contribute to the improvement in organizational performance and competitive advantage (Lee et al., 2006). To optimize supply chain performance, information about forecast, sales, promotional activities must be shared not only among the internal functions but also across the supply chain (Bowersox et al., 2000).

The quality and quantity of information are important attributes which need to be stressed in information sharing. Monczka et al., (1998) defines information sharing as the 


\section{International Journal of Science and Research (IJSR) \\ ISSN (Online): 2319-7064 \\ Index Copernicus Value (2013): 6.14 | Impact Factor (2015): 6.391}

level of information that is being communicated to the supply chain members or partners which is critical and proprietary in nature.

Effective Information sharing also relates to activities of distributing useful information among people, systems or organizational unit in an open environment. Information sharing should address the following issues; _what to share', whom to share', how to share', and „when to share' of which if properly addressed would minimize sharing cost, information deficiency or overload and improve supply chain responsiveness, this according to (Sun and Yen, 2005).

The ability of firms to gain competitive advantage and to ensure product availability in supply chain is determined by how information is used in the supply chain (Mason-Jones and Towill, 1997)

Information has little value if it is not shared among the supply chain partners. Trust among the supply chain partners seems to have influence on the information flow in supply chain. However, due to lack of trust, certain information may be withheld from supply chain partners. Relationship among supply chain members, which is based on trust and commitment, would facilitate information sharing among supply chain partners ( Moberg et al., (2002). In support of this, Kwon and Suh (2004) noted that information sharing reduces the level of behavioral uncertainty, which lead to improvement in the level of trust.

High level of information sharing and information quality is influenced by successful partner relationship (Monczka et al., 1998; Mason-Jones and Towill, 1997). However, the confidentiality of the information or privacy may influence the level of information sharing in the supply chain ( $\mathrm{Li}$ et al., 2006). Consequently supply chain partners need to decide on the types of information that need to be shared. Supply chain partners should be aware of the information which is deemed relevant that must be shared with the supply chain partners for the successful functioning of the supply chain.

Oluka et al, (2010) observed that despite Uganda's commitment to improve drug access and availability, actual realization remains low and structural bottlenecks in the have not been identified and documented. Structural bottlenecks at each stage of the supply have not been systematically identified and documented as a starting point. The findings from the cross sectional survey conducted on 240 respondents in four malaria prone districts indicated that hospitals were mainly affected by lack of credible and accessible drug consumption information, poor planning, forecasting and logistics. Health Centre IVs mainly faced inadequate procurement skills and consumption information. Health Centre IIIs encountered poor procurement practices and logistics

\section{Methodology}

The study adopted a descriptive and analytical cross sectional survey, with mixed research methods approach, (Onwuegbuzie \& Johnson, (2006); Greene (2006); Greene, Caracelli, and Graham (1989); Gray (2004). Principal Component Analysis was carried out on the indicators using both Factoring out principle component and Varimax Rotation the survey assessed in detail the information flow management as a key component of the medical store management in relation to the effectiveness of the supply chain of medicines in the selected hospitals. Both quantitative and qualitative data collection methods were used. Standardized checklists, interviewer guide and questioners were used to collect data. A total of 6 purposively selected hospitals were studied with all (30) pharmacy, medical stores and hospital heads as purposively as respondents.

\section{Results}

\section{Demographic characteristics of the respondents}

The study was conducted in six hospitals; these were Abim, Atutur, Kawolo and Bwera General Hospitals and Fort Portal, Soroti Regional Referral hospitals. Of the 38 purposively selected respondents only four persons did not respond to the study giving a response rate of $92.1 \%$. However, of the 35 who responded only 30 provided both qualitative and quantitative information and the other 4 provided only qualitative information. Of the 30 who responded 11 (36.7\%) were from the Regional Referral Hospitals and the 19 (63.3\%) were from the General Hospitals and the highest number of persons who were handling medicines were under others 10 (33.3\%) under these are the volunteers, nurses and non-qualified persons. This observation raises concerns to whether these persons are competent enough to handle medical stores as they are not qualified and lack basic knowledge in handling medical stores. On the aspect of experience, the highest percentage of $46.6 \%$ had worked in their current jobs for more than 11 years .However; majority $57.1 \%$ had not gotten any related training in the last 6 months

\section{Level of information sharing}

Generally $40 \%$ of the respondents were in the disagreement about the sharing of business unit's proprietary information, whereas another $40 \%$ generally agreed. However, $20 \%$ of the respondents did not know as to whether this information was being shared or not and yet they are actually members of the downward supply chain. Similarly as to whether the supplier informs the hospitals in advance of the changes in supplies related issues, $53.3 \%$ of the respondents agreed, $36.7 \%$ disagreed and only $10 \%$ did not know. This lack of sharing information in advance as regards creates a gap in planning for any probable delays that may occur in the supply chain. Some hospitals may not be able to put in place contingency measures in place to bridge the gaps that the changes in supply may incur.

As regard as to whether hospitals and their suppliers share information which might be useful for each other to establish supplies, $66.6 \%$ of the respondents agreed, $30 \%$ were in disagreement and only $3.4 \%$ did not know. As to whether the supplier provides advance notices to the hospitals 53.3\% agreed and $46.7 \%$ disagreed. Overall the apart from sharing of the distribution schedules which most respondents agree, there a balance of views on the level of information sharing that could be contributing to the ineffectiveness of the supply chain. There is need therefore to enhance this sharing of 


\section{International Journal of Science and Research (IJSR) \\ ISSN (Online): 2319-7064 \\ Index Copernicus Value (2013): 6.14 | Impact Factor (2015): 6.391}

information that is vital for ensuring the availability of essential medicines and health supplies.

Table 1: Level of Information sharing between hospitals and NMS

\begin{tabular}{|c|c|c|c|}
\hline Variable & Indicator/ response & Frequency(f) & Percentage (\%) \\
\hline \multirow{6}{*}{$\begin{array}{l}\text { We and our supplier share } \\
\text { business units proprietary } \\
\text { information }\end{array}$} & 1. Strongly Disagree & 3 & 10.0 \\
\hline & 2. Disagree & 9 & 30.0 \\
\hline & 3. I don't know & 6 & 20.0 \\
\hline & 4. Agree & 6 & 20.0 \\
\hline & 5. Strongly agree & 6 & 20.0 \\
\hline & Total & 30 & 100 \\
\hline \multirow{6}{*}{$\begin{array}{l}\text { Our supplier informs us in advance } \\
\text { of the changes in supplies related } \\
\text { issues }\end{array}$} & 1. Strongly Disagree & 3 & 10.0 \\
\hline & 2. Disagree & 8 & 26.7 \\
\hline & 3. I don" $t$ know & 3 & 10.0 \\
\hline & 4. Agree & 10 & 33.3 \\
\hline & 5. Strongly agree & 6 & 20.0 \\
\hline & Total & 30 & 100 \\
\hline \multirow{6}{*}{$\begin{array}{l}\text { We and our suppliers share } \\
\text { information which might be useful } \\
\text { for each other to establish supplies }\end{array}$} & 1. Strongly Disagree & 1 & 3.3 \\
\hline & 2. Disagree & 8 & 26.7 \\
\hline & 3. I don't know & 1 & 3.3 \\
\hline & 4. Agree & 10 & 33.3 \\
\hline & Strongly agree & 10 & 33.3 \\
\hline & Total & 30 & 100 \\
\hline \multirow{6}{*}{$\begin{array}{c}\text { We exchange core supply } \\
\text { processes and knowledge with our } \\
\text { supplier }\end{array}$} & 1. Strongly Disagree & 3 & 10.0 \\
\hline & 2. Disagree & 7 & 23.3 \\
\hline & 3. I don't know & 6 & 20.0 \\
\hline & 4. Agree & 11 & 36.7 \\
\hline & 5. Strongly agree & 3 & 10.0 \\
\hline & Total & 30 & 100 \\
\hline \multirow{6}{*}{$\begin{array}{l}\text { We and our supplier share } \\
\text { information even without specified } \\
\text { agreement }\end{array}$} & 1. Strongly Disagree & 5 & 16.7 \\
\hline & 2. Disagree & 10 & 33.3 \\
\hline & 3. I don't know & 1 & 3.3 \\
\hline & Agree & 11 & 36.7 \\
\hline & Strongly agree & 3 & 10.0 \\
\hline & Total & 30 & 100 \\
\hline \multirow{5}{*}{$\begin{array}{l}\text { Our supplier provides advanced } \\
\text { notices to us about our supplies }\end{array}$} & 1. Strongly Disagree & 8 & 26.7 \\
\hline & 2. Disagree & 6 & 20.0 \\
\hline & 3. Agree & 9 & 30.0 \\
\hline & 4. Strongly agree & 7 & 23.3 \\
\hline & Total & 30 & 100 \\
\hline \multirow{4}{*}{$\begin{array}{l}\text { Our supplies share distribution } \\
\text { schedule with us }\end{array}$} & 1. Disagree & 5 & 16.7 \\
\hline & 2. Agree & 14 & 46.7 \\
\hline & Strongly agree & 11 & 36.7 \\
\hline & Total & 30 & 100 \\
\hline
\end{tabular}

\section{Source: Primary data}

\section{Hypothesis test results}

The chi square test was used at 5\% level of significance, to test whether the variables of interest for each set of hypothesis had a significant relationship with the outcome variable or not. Further tests were also done to determine the extent to which the significant variables were responsible for the variations in the outcome variable. This was done for each variable at a time, in the absence of a confounding factor.

The outcome variable that was taken to be the best presenter of any confounding factors among the group of variables that moved out to measure effectiveness of supply chain was variable "no out of stock of essential medicines in the hospitals"

The hypothesis tested was to determine whether there is "no significant relationship between the information flow management systems and the effectiveness of the supply chain of the essential medicines".

No out of stock of essential medicines in hospitals" was taken as the best measure of the supply chain effectiveness.

Table 2: Information on changes in supply and no out of stock of essential medicines

\begin{tabular}{|c|c|c|c|c|c|c|c|}
\hline Variable & \multirow[t]{2}{*}{ Indicator } & \multicolumn{6}{|c|}{ "No out of stock of essential medicines in the hospitals" } \\
\hline \multirow{4}{*}{$\begin{array}{l}\text { Our suppliers informs us } \\
\text { in advance of the } \\
\text { changes in supply } \\
\text { related issues }\end{array}$} & & $* *$ Satisfactory & **Unsatisfactory & Total & O.R & $\chi^{2}$ & P-value \\
\hline & Agree** & 9 & 9 & 18 & \multirow{3}{*}{6.0} & \multirow{3}{*}{15.30} & \multirow{3}{*}{0.005} \\
\hline & Disagree** & 2 & 10 & 12 & & & \\
\hline & Total & 11 & 19 & 30 & & & \\
\hline
\end{tabular}

$\mathbf{R}^{2}=\mathbf{0 . 5 2 1}$ 


\section{International Journal of Science and Research (IJSR) \\ ISSN (Online): 2319-7064 \\ Index Copernicus Value (2013): 6.14 | Impact Factor (2015): 6.391}

When variable, -or supplier informs us in advance of their changes in supply related issues", was found to be significantly associated with variable "no out of stock of essential medicines in the hospitals". This is because $\chi^{2}=15.296$ was greater than the test value of 3.864 and the $\mathrm{p}$ value of 0.005 being less than 0.05 .

The odds ratio of 6 implies that hospitals that are informed of the changes in supply related issues are six times more likely to have medicines in stock than those that are not informed by the suppliers. This could be, as result of the information, contingency measures can be put in place to cater for the gaps that may be created by the change, and those hospital with no such notifications are usually taken unaware. Considering the coefficient of determination in a model fitted for this variable, one can conclude that if this variable is left to vary the outcome variable "no out of stock of essential medicines in the hospitals" alone, we can say confidently say that $52.1 \%$ of the variations that will be observed in the outcome variable, will be as a result of its dependency on suppliers informing hospitals in advance of their changes in supply related issues (Table 2)

Ntayi et al., (2008) observed that collaborative linkages consists of three dimensions, namely information sharing, decision harmonization and better coordination, all resulting in order fulfillment and assurance that deliveries are made on time facilitated by information technology facilities. And according to (Lee et al. 1997; Whipple et al. 2002), Information sharing enables chain members to create better performance in terms of reduced stock outs. The more firms share information, the more efficient the supply chain (Ramdas and Spekman, 2000). Ntayi (2008) argues that collaborative planning of activities reduces the gap between delivery requirements and actual delivery, thereby improving customers" perceptions of fulfillment performance. The findings above are therefore in line with the earlier observations made by different scholars. So it is therefore important that business organizations in this case the hospitals and NMS enhance their level of information sharing in order for the supply chain to as effective as possible.

However, Eisen Alexander et al., (2005) noted that many times because of the nature of supply chain dynamics, managers often do not have insight into the ripple effects of their decisions. Effects also can easily get lost in the overwhelming flood of data that crosses the supply chain managers' desk daily, weekly, or monthly. A rapidly changing supply chain with a continuous change of partners leads to different sets of decisions than a stable chain with long-term contracts

But overall they agree that sharing information in the supply chain enhances its effectiveness

Table 3: Sharing supply planning information and $-\mathbf{a}$ out of stock of essential medicines

\begin{tabular}{|c|c|c|c|c|c|c|c|}
\hline Variable & \multirow[t]{2}{*}{ Indicator } & \multicolumn{6}{|c|}{ "No out of stock of essential medicines in the hospitals" } \\
\hline \multirow{4}{*}{$\begin{array}{l}\text { We and our supplier share } \\
\text { information which might } \\
\text { be useful for each other to } \\
\text { carry out supplies } \\
\text { blanning }\end{array}$} & & **Satisfactory & **Unsatisfactory & Total & O.R & $\chi^{2}$ & P-value \\
\hline & Agree** & 6 & 14 & 20 & \multirow{3}{*}{1.7} & \multirow{3}{*}{14.79} & \multirow{3}{*}{0.007} \\
\hline & Disagree** & 2 & 8 & 10 & & & \\
\hline & Total & 8 & 22 & 30 & & & \\
\hline
\end{tabular}

$\mathbf{R}^{2}=\mathbf{0 . 6 1}$

Sharing of information for supplies planning between the hospitals and the suppliers was found to a significant factor in influencing the variable "no out of stock of essential medicines in the hospitals" since the $\chi^{2}=14.79>3.864$ and $\mathrm{p}$ value of $0.007<0.05$.

Considering the coefficient of determination, one can also conclude that if this variable was left to vary "no out of stock of essential medicines in the hospitals", $61 \%$ of the variation in the outcome variable "no out of stock of essential medicines in the hospitals", if left alone will be due to its dependency on sharing information for supplies planning between the hospitals and the suppliers. A hospital which was sharing information for supplies planning with the suppliers was 1.7 times more likely to have medicines as compared to those hospitals that were not sharing such information with their suppliers. This also means that hospitals that were not sharing information with suppliers that was useful to carry out supply planning were more likely to encounter out of stock of essential medicines (Table 3).

For proper planning to be done accurate, complete, relevant and timely information is required. The findings of this study are in line with the observations that were made by (Samaddar et al., (2006); Lambert (2004) who highlighted the role of information in ensuring an effective supply chain. It therefore important that parties in the supply chain share relevant information, as this will enhance the effectiveness of the supply chain.

Table 4: Sharing of distribution schedules and no out of stock of essential medicines

\begin{tabular}{|c|c|c|c|c|c|c|c|}
\hline Variable & \multirow[t]{2}{*}{ Indicator } & \multicolumn{6}{|c|}{ "No out of stock of essential medicines in the hospitals" } \\
\hline \multirow{4}{*}{$\begin{array}{l}\text { Our supplier shares } \\
\text { distribution schedules } \\
\text { with us }\end{array}$} & & $* *$ Satisfactory & **Unsatisfactory & Total & O.R & $\chi^{2}$ & P-value \\
\hline & Agree** & 16 & 10 & 26 & \multirow[t]{3}{*}{1.6} & \multirow[t]{3}{*}{23.329} & \multirow[t]{3}{*}{0.003} \\
\hline & Disagree** $^{* *}$ & 2 & 2 & 4 & & & \\
\hline & Total & 18 & 12 & 30 & & & \\
\hline
\end{tabular}

$\mathbf{R}^{2}=\mathbf{0 . 9 7 2}$

Variable, haring distribution schedules with hospitals, was found to be significantly associated with variable "no out of stock of essential medicines in the hospitals" as its $\chi^{2}$-value $=23.329>3.864$ and p-value $=0.003<0.05$.
Considering the coefficient of determination of 0.972 (97.2\%) one can say that if variable — staring distribution schedules is left to vary variable "no out of stock of essential medicines in the hospitals" alone, then we can say that

\section{Volume 5 Issue 4, April 2016}




\section{International Journal of Science and Research (IJSR) \\ ISSN (Online): 2319-7064 \\ Index Copernicus Value (2013): 6.14 | Impact Factor (2015): 6.391}

$97.2 \%$ of the total variation that will be observed in the variable "no out of stock of essential medicines in the hospitals", will be as a result of its dependency on sharing of distribution schedules between the hospitals and the suppliers. Hospitals that were sharing distribution schedules with suppliers were 1.6 times more likely to have their essential medicines in stock all the time as compared to those hospitals that were not sharing such distribution schedules with suppliers (Table 4)

Distribution schedules are innovations from the supplier to ensure a cost effective delivery of essential medicines and health supplies. It is structure in a way that health facilities in on direction or region are grouped together and put under one route.

Table 5: Knowledge of inventory levels and no out of stock of essential medicines

\begin{tabular}{|c|c|c|c|c|c|c|c|}
\hline Variable & \multirow[t]{2}{*}{ Indicator } & \multicolumn{6}{|c|}{ "No out of stock of essential medicines in the hospitals" } \\
\hline \multirow{4}{*}{$\begin{array}{l}\text { We and our } \\
\text { supplier know each } \\
\text { other inventory } \\
\text { level quiet well }\end{array}$} & & **Satisfactory & **Unsatisfactory & Total & O.R & $\chi^{2}$ & P-value \\
\hline & Agree** & 6 & 6 & 12 & \multirow{3}{*}{3.5} & \multirow{3}{*}{22.368} & \multirow{3}{*}{0.034} \\
\hline & Disagree** $^{* *}$ & 4 & 14 & 18 & & & \\
\hline & Total & 10 & 20 & 30 & & & \\
\hline
\end{tabular}

$\mathbf{R}^{2}=\mathbf{0 . 7 0 9}$

Variable -supplier knowing each other's inventory levels quiet well" was found to be a significant factor in explaining variable "no out of stock of essential medicines in the hospitals", since its chi square value is 22.368 which is greater than the test value of 3.864 and the $p$-value $=0.034<$ 0.05

Looking at the coefficient of determination, on can be $95 \%$ confident that, in the absence of all the rest of the variables in the model, $70.9 \%$ of the variation observed in the variable out of stock of essential medicine will be as a result of its dependency on suppliers knowing each other's inventory levels quiet well. Health facilities that were in the know of the supplier's inventory level quiet well as well as the supplier knowing their inventory levels were 3.5 times more likely to have their essential medicines in stock all the time (Table 5).

Table Error! No text of specified style in document.: Exchange of pricing strategies and no out of stock of essential medicines

\begin{tabular}{|c|c|c|c|c|c|c|c|}
\hline Variable & \multirow[t]{2}{*}{ Indicator } & \multicolumn{6}{|c|}{ "No out of stock of essential medicines in the hospitals" } \\
\hline \multirow{4}{*}{$\begin{array}{l}\text { We exchange } \\
\text { pricing strategies } \\
\text { with our suppliers }\end{array}$} & & $* *$ Satisfactory & **Unsatisfactory & Total & O.R & $\chi^{2}$ & P-value \\
\hline & Agree** & 2 & 4 & 6 & \multirow{3}{*}{0.1} & \multirow{3}{*}{15.916} & \multirow{3}{*}{.019} \\
\hline & Disagree** $^{* *}$ & 20 & 4 & 24 & & & \\
\hline & Total & 22 & 8 & 30 & & & \\
\hline
\end{tabular}

$\mathbf{R}^{2}=\mathbf{0 . 5 4 2}$

As shown in table 6 exchanging pricing strategies between health facilities and suppliers, was found to be significantly associated with variable "no out of stock of essential medicines in the hospitals" since the chi-square value of 15.916 is greater than the test value of 3.864 and same conclusion was arrived at by considering the p-value of 0.019 which is less than 0.05 .

In addition the coefficient of determination shows that, if we are to let this variable - rechanging pricing strategies between health facility and supplier" alone to vary the outcome variable, then we can be $95 \%$ confident that $54.2 \%$ of the total variations in the "no out of stock of essential medicines in the hospitals", will be due to its dependency on variable -xchanging pricing strategies between hospitals and suppliers. In terms of the odds ratio, hospitals that were exchanging such pricing strategies with the supplier were 0.09 times less likely to encounter out of stock of essential medicines.

Table 7 Supplier knowledge of demand and tho out of stock of essential medicines

\begin{tabular}{|c|c|c|c|c|c|c|c|}
\hline Variable & \multirow[t]{2}{*}{ Indicator } & \multicolumn{6}{|c|}{ "No out of stock of essential medicines in the hospitals" } \\
\hline \multirow{4}{*}{$\begin{array}{l}\text { Our supplier } \\
\text { knows our } \\
\text { demands very } \\
\text { well }\end{array}$} & & **Satisfactory & **Unsatisfactory & Total & O.R & $\chi^{2}$ & P-value \\
\hline & Agree** & 2 & 6 & 8 & 3.3 & 19.024 & 0.0024 \\
\hline & Disagree** & 2 & 20 & 22 & & & \\
\hline & Total & 4 & 26 & 30 & & & \\
\hline
\end{tabular}

In the table 7 , variable, supplier knowing the new demands of the hospital very well, was proved to be significant in explaining the outcome variable "no out of stock of essential medicines in the hospitals". This is shown by the chi-square value of 19.024 which is greater than the test value of 3.864 and p-value of 0.0024 which is less than 0.05 . And the hospitals, whose suppliers knew their new demands, very well, were 3.3 times more likely to have their essential medicines stocks in stock.

\section{Multivariate Analysis}

In order to assess the relationship between the medical stores management practices which was the independent variable and the effectiveness of the supply chain of essential medicines which was the dependent variable, all the factors of the three constructs that were significant at bi-variate level were subjected to a multivariate analysis using logistic regression model. A Back Ward Stepwise Logistic 


\section{International Journal of Science and Research (IJSR) \\ ISSN (Online): 2319-7064 \\ Index Copernicus Value (2013): 6.14 | Impact Factor (2015): 6.391}

Regression was used to control for all probable confounding variables in the test.

Table 8: Information Flow Management and the Effectiveness of the supply chain

\begin{tabular}{|c|c|c|c|c|}
\hline Variable & Indicator & Adjusted OR & 95\% CI Adjusted OR & P-value \\
\hline $\begin{array}{l}\text { Supplier and the health facilities sharing } \\
\text { information which might be of use for each } \\
\text { other to establish supplies planning, }\end{array}$ & $\begin{array}{c}\text { Agree* } \\
\text { Disagree* }\end{array}$ & 5.2 & $3.20-8.63$ & $0.0005^{* *}$ \\
\hline Suppliers knowing the hospital new demands & $\begin{array}{c}\text { Agree* } \\
\text { Disagree* }\end{array}$ & 1.5 & $1.29-2.54$ & $0.005 * *$ \\
\hline $\begin{array}{c}\text { Our supplier /customers sharing distribution } \\
\text { schedules }\end{array}$ & $\begin{array}{c}\text { Agree* } \\
\text { Disagree* }\end{array}$ & 1.4 & $1.02-1.93$ & $0.002 * *$ \\
\hline $\begin{array}{c}\text { We and our supplier know each other } \\
\text { inventory level quite well }\end{array}$ & $\begin{array}{c}\text { Agree* } \\
\text { Disagree* }\end{array}$ & 3.8 & $2.10-6.34$ & $0.004 * *$ \\
\hline Exchange of pricing strategies, & $\begin{array}{c}\text { Agree* } \\
\text { Disagree* }\end{array}$ & 0.7 & $-0.20-0.30$ & $0.002 * *$ \\
\hline Our supplier know our demands very well & $\begin{array}{c}\text { Agree* } \\
\text { Disagree* }\end{array}$ & 3.2 & $2.31-6.90$ & $0.000 * *$ \\
\hline
\end{tabular}

\section{Overall impression/ conclusion}

From the above tests, one can conclude that there is a significant relationship between the information flow management systems and the effectiveness of the supply chain of the essential medicines as all the aspects tested have showed that. Therefore hospitals should ensure that the information sharing with the supplier is enhanced as this has been proven to influence the effectiveness of the supply chain.

\section{Recommendations}

- Improved sharing of information that is accurate, timely and complete

- Development of computerized medicines management systems in the hospitals

- Collaborative procurement planning at all levels

- Improvement in records and record keeping.

- Enhancement of online communication between the hospitals and the suppliers

\section{References}

[1] Agarwal A, Sharkar R (2002). Modeling supply chain performance variables. Asian academy of management. Vol.10(2): 47-68.

[2] Amin, M. E. (2005). Social Science Research: Conception, Methodology and Analysis. Kampala Makerere University Printery.

[3] Annual Health Sector Performance Report (AHSPR 2013) of Uganda

[4] Bamberger, M. (2000).Integrating quantitative and qualitative research in development projects: Direction in development series, Washington, DC: The World Bank

[5] Banker, R. D., I. R. Bardhan, et al. (2006). "Plant information systems, manufacturing capabilities, and plant perfor mance." MIS Quarterly 30(2): 315-337.

[6] Bardhan, I., J. Whitaker, et al. (2006). "Information Technology, Production Process Outsourcing, and Manufacturing Plant Performance." Journal of Management Information Systems 23(2): 13-40.

[7] Barney, (2012) Firms resources and and supply chain performance. Journal of Management.
[8] Barney, J. (1991). "Firm Resources and Sustained Competitive Advantage." Journal of Management 17(1): 99.

[9] Barney, J. (1991). Firm resources and sustained competitive advantage. Journal of Management, 17, 99-120.

[10] Barney, J. (1986). Resource-based theories of competitive advantage: A ten-year retrospective on the resource-based view. Journal of Management, 27, 643650.

[11] Barratt M (2004). Understanding the meaning of collaboration in the supply chain. Supply. Chain. Management, 9(1): 31-42.

[12] Becker, C. et al., (2004) A dose of higher costs. Modern Healthcare 34(6) 4-11.

[13] Becker, G. S. (1983). Human capital: A theoretical and empirical analysis with special reference to education. Chicago, IL: University of Chicago Press.

[14] Black RE, Morris SS, Bryce J. Where and why are 10 million children dying every year? Lancet (2003);361: 2226-34. [PubMed]

[15] Boaduo, N. A. P. (2005). Methodological Choice and Application in a Research Study: A Framework for Practitioners. In the African Symposium, 5(3): 88-101.

[16] Boaduo, N. A. P. (2006). Methodological Choice and Application in a Research Study: A Framework for Practitioner in Lonaka: Bulletin of the Centre for Academic Development Quality Assurance in Higher Education".

[17] Boyce, C. \& Neale, P. (2006) Conducting In-depth Interviews: A guide for Designing and conducting indepth interviews for evaluation input. Pathfinder International. Tool Series.

[18] Bryman, A. (2012). Social Research Methods (4 ${ }^{\text {th }}$ Ed.). Oxford University Press, New York.

[19] Bowersox, D. J., Closs, D.J. and Theodore, S.P (2000). "Ten Mega Trends That Will Revolutionalise supply chain Logistics", (21:2), 2000, pp. 1-16.

[20] Buchan, J and Dovlo, D., 2000. International recruitment of health workers to the UK: A report for DIFD.

http://www.difdhealthrc.org/shared/publications/reports int_rec/int-rec-main.pdf

[21] Buren, H 2008. Fairness and the main management theories of the twentieth century: a historical review, 


\section{International Journal of Science and Research (IJSR) \\ ISSN (Online): 2319-7064}

Index Copernicus Value (2013): 6.14 | Impact Factor (2015): 6.391

1900-1965. Journal of Business Ethics, 82(3), pp.663644.

[22] Chandler, A. D. (1962). Strategy and structure: Chapters in the history of American industrial enterprise. London, England: MIT Press.

[23] Chauduri. S., et al., (2010), Indian Generic Producers, access to Essential Medicines and local production in Africa. An Argument with reference to Tanzania European Journal of Development Research 22. 451468 Available at: http://www.pagravejournals.com/ejdr/journal/v22/n4/full/ejdr201027a.html Accessed 24.10.2014.

[24] Chen L, Evans T, Anand S, Boufford JI, Brown H, Chowdhury M, et al. (2004). Human resources for health: overcoming the crisis. Lancet 2004;364: 198490. [PubMed]

[25] Chibba,\& Rundqvist, (2011). Mapping flows - An analysis of the information flows within the Integrated supply chain. Proceedings of the 16th Annual Conference for Nordic Researchers in Logistics

[26] Child, D. (1990). The essentials of factor analysis, second edition. London: Cassel Educational Limited.

[27] Churchill, G.A., 1979. A paradigm for developing better measures of marketing constructs. Journal of Marketing Research 16 (2), 64-73.

[28] Cigolini, et al. (2004) Supply chain efficiency in automobile industries (Oxford Press

[29] Coff, R. W. (2002). Human capital, shared expertise, and the likelihood of impasse on corporate Acquisitions. Journal of Management, 28, 107-128.

[30] Combs, J., Liu, Y., Hall, A., \& Ketchen, D. (2006). How much do high-performance work Practices matter? A meta-analysis of their effects on organizational performance. Personnel Psychology, 59, 501-528.

[31] Copacino (1996). Performance of the Supply Chain of Medicines in ensuring availability of Medicines.

[32] Council of Supply Chain Management Professionals (CSCMP 2006)

[33] Cronbach, L. J., 1951. Test validation. In: Thorndike, R.L. (Ed.), Educational Measurement, 2nd ed. American Council on Education, Washington, DC, pp. 443-507.

[34] Croom et al. (2000)The Impact of E-business on Supply Chain Management: an Empirical Study of Key Developments, International J. Operations and 36. Waller, M., M.E. Johnson and T. Davis, 1999. Production Management, 25(1): 55-73.

[35] Deininger K, Mpuga P. (2004) Abolition of user fees in the public sector: Enhanced uptake Health care services

[36] Dierickx and Cool (1995) Purchasable assets as no premise of sustainable competitive advantage in perfect markets economies.

[37] Dillman, D.A., (1978). Mail and Telephone Surveys: The Total Design Method. Wiley, New York

[38] Disease Control Project (2006) Availability of Essential Medicines and Health Supplies (USAID)

[39] Dukes, G. (2005), Moving forward-now! Presented at the Strategies for Enhancing Access to Medicines Conference, Accra, Ghana, 20-22 June 2005. www.msh.org/seam/conference2005

[40] Economic Policy Research Cetre, 2010.Governing Health Service Deivery In Uganda. A racking Study Of
Drug Delivery Mechanism, P.X. Available At: http://Www.Eprc.Or.Ug/Pdf_Files/Research_Report1.P df. Accessed 19.10.2014.

[41] Eisen A (2005). Achieving a High-Performance Supply Chain: Sharing Information with Partners. Bus. Intelligence. J., 13(2): 29-37.

[42] Ember, C. R. \& Ember, M. (2001). Cross-Cultural Research Methods. New York:Rowman \& Littlefield.

[43] Emory, C.W., 1980. Business Research Methods. Richard D. Irwin, Homewood, IL.

[44] Fisher, J., \& Govindarajan, V. (1992). Profit center manager compensation: An examination of market, political and human capital factors. Strategic Management Journal, 13, 205-217

[45] Funda B.K et al,. 2010; Problems and Perspectives in Management, Volume 8, Issue 1)

[46] Fundafunda, B. (2007). Transparency and Accountability in the supply of Medicines. MeTA expert consultation meeting London $28^{\text {th }}$ February - 1 st March $2007 \quad$ (Available on www.dfidhealthrc.org/)Global Emergency Group (2010). Health Commodities Supply Chain Assessment in Karamoja Region Uganda.

[47] Global Fund for HIV/AIDS, Tuberculosis and Malaria.(2005). HIV/AIDS, tuberculosis and Malaria: the status and impact of the three diseases. Geneva: Global Fund.

[48] Global Emergency Group. 2010.

[49] Golafshani, N. (2003). Understanding Reliability and Validity in Qualitative Research. The Qualitative Report 8(4): 597-607.

[50] Grant, R. M. (1991). The resource-based theory of competitive advantage: Implications for strategy formulation. California Management Review, 33, 114136.

[51] Grant, R. M. (1991). Prospering in dynamicallycompetitive environments: Organizational capability as knowledge integration. Organization Science, 7, 375387.

[52] Gray D. E. (2004).Doing Research in the Real World. London: SAGE Publications.

[53] Greene, J. C. (2006). Toward a methodology of mixed methods social inquiry. Research in the Schools, 13(1), 93-98.

[54] Greene, J. C., Caracelli,V. J., \& Graham,W. F. (1989). Toward a conceptual framework for Mixed-method evaluation designs. Educational Evaluation and Policy Analysis, 11, 255- 274.

[55] Gustin CM, Daugherty PJ, Stank TP (1995). The effects of information availability on logistics integration. J. Bus. Logistics., 16(1): 1-21.

[56] Hambrick, D. C., \& Mason, P. A. (1984). Upper echelons: The organization as a reflection of its top managers. Academy of Management Review, 9, 193206.

[57] Hanke, J. \& Kassowiski, T. (2011). Comparison of Value of Pearson's and Spearman's Correlation Coefficients on the Same Sets of Data. Questiones Geographicae 30(2): 87-93.

[58] Harris, D., \& Helfat, C. (1997). Specificity of CEO human capital and compensation. Strategic Management Journal, 18, 895-920

\section{Volume 5 Issue 4, April 2016




\section{International Journal of Science and Research (IJSR) ISSN (Online): 2319-7064 \\ Index Copernicus Value (2013): 6.14 | Impact Factor (2015): 6.391}

[59] Harris, F. M. (1913) - Idw Many Parts to Make at Once," Factory, The Magazine of Management 10:2, 135-136, 152. Reprinted in Operations Research 38:6 (1990), 947-950.

[60] Hoopes, Madsen and Walker, (2003) Criticism on the Resource Based Theory

[61] Hugos, Michael H. (2011). Essentials of Supply Chain Management. United States of America: John Wiley \& Sons.

[62] Hull, C.H., Nie, N.H., (1981). SPSS Update. McGrawHill, New York.

[63] James, R., Rich, N. \& Francis, M. (1996). Vendor Managed Inventory: A Procession Approach, In Proceedings: 5th International IPSERA Conference, Eindhoven University of Technology (TUE), Eindhoven, Netherlands

[64] John Kenneth Galbraith in (1969),Intellectual Capital in organizations. National Taipei University, R.O.C.

[65] Johnson \& Onwuegbuzie, (2004) Mixed research methods: A research Paradigm. Whose time has come? Vol 33 no 7 14-26 Sage Publishers.

[66] Jones, O. (1997). Information in the Supply Chain: Media and Message, In: Cox, A. and Hines, P., Advanced Supply Chain Management: The Best Practice Debate, London, Earlsgate Press

[67] Kajornboon, A. B. (2004).Creating Useful Knowledge: A Case Study of Policy Development in E-Learning at Chulalongkoran University Language Institute. Dissertation. University of Melbourne: Australia.

[68] Kar Yan, T. (1998). "The Impact of Information Technology Investments on Firm Performance and Evaluation: Evidence from Newly Industrialized Economies." Information Systems Research 9(1): 85.

[69] Kearney A.T. Inc, (2004); Improving the medicines supply chain

[70] Kiapi, S., (2009). What is Causing Drug Shortages in Uganda? A publication of the health rights advocate. Available http://healthrightsadvocate.blogspot.com/2009/05/what -is- causing-drug-shortages-in.html. Accessed on April 27, 2013.

[71] Kulkarni, Sarika \& Sharma, Ashok, (2004). Supply chain management. Tata McGraw-Hill Publishing

[72] Kvale, D. (1996). An Introduction to Qualitative research Interviewing. London. SAGE Publications.

[73] Lambert, D. M., Cooper, M. C., et al. (1998). Supply Chain Management: Implementation Issues and Research Opportunities. The International Journal of Logistics Management, 9, 2,1- 19.

[74] Lee, H.L., Padmanabhan, V. and Whang, S. (1998). The Bullwhip Effect in Supply Chains", Sloan Management Review, (38:3), pp. 93- 102.

[75] Lee, H. L. and Whang, S.(2000). Information sharing in a supply chain. International Journal of Technology Management, V20, 3, 373-387.

[76] Lippman and Rumelt (1982). Is of the inter firm differences in efficiency under competition. Bell Journal of economics 13:418-438.

[77] Lokollo, E.M (2004). Linking Farmers with Markets: Ways to Reduce Poverty Through Supply Chain Management. 4th International Agroenviron 2004 Symposium Beijing, P. R. China, Management
Sciences for Health. 2004. Management Sciences for Health. Sep. 15, 2005. <http://www.msh.org.

[78] Masom-Jones. R \& Towill D (1997), Information Enrichment, designing the supply chain for a competitive advantage. Supply chain Management. An International Journal 2(4),137-148.

[79] Mbwasi R. Using a holistic approach to transform private sector drug outlets: the Tanzania experience. Presented at the Strategies for Enhancing Access to Medicines Conference, Accra, Ghana 20-22 June 2005. www.msh.org/seam/conference2005 (accessed 22 Sep 2011).

[80] Mendis et al (2007). Availability and Affordability of Essential Medicines for chronic diseases in six low and middle income countries. Bull WHOvol. 85.n.4 Genebra.

[81] Ministry of Health, Uganda National Drug Policy, (2002).

[82] Ministry of Health. (2008). WHO Pharmaceutical Situation Assessment - Level II - Health Facilities Survey in Ghana. Accra: Ministry of Health, Ghana.

[83] Ministry of Health (2005), Health Sector Strategic Plan 2004/05-2009/10, Kampala, Uganda.Ministry of Health (House hold survey 2008)

[84] Ministry of Health. (2009). A Rapid Assessment of Community Case Management of Childhood Malaria, Pneumonia and Diarrhoea in the Context of Home Based Management of Fever (HBMF) and Home Based Care $(\mathrm{HBC})$ in Northern Uganda. Kampala.

[85] Ministry of Health. 2009c. Annual Health Sector Performance Report: Financial Year 2008/2009. Kampala.

[86] Ministry of Health (2009e). Uganda National Communication Strategy for Promoting Rational Use of Medicines. Kampala.

[87] Ministry of Health. (2010a). Health Sector Strategic and Investment Plan 2010/11-2014/15. Kampala.

[88] Ministry of Health. ( 2010). Status of Antiretroviral Therapy Service Delivery in Uganda. Kampala: AIDS Control Program, Ministry of Health

[89] Ministry of Health (2008), National Health Policy: Promoting People's Health to enhance Economic growth

[90] Ministry of Health (2005, 2010): Management of Drugs and Supplies.

[91] Mitra, S. and A. K. Chayam (1996). "Analyzing costeffectiveness of organizations: The impact of information technology spending." Journal of Management Information Systems 13(2): 2

[92] Moberg CR, Cutler BD, Gross A, Speh TW (2002). Identifying antecedents of information exchange within supply chains. Int. J.Physical. Distribution. Logistics., 32(9): 755-770.

[93] Monczka RM, Petersen KJ, Handfield RB, Ragatz GL (1998). Success factors in strategic supplier alliances: The buying company perspective. Decision. Sci., 29(3): 553-577.

[94] Morgan, J.P., Zimmerman, S., (1990). Building worldclass supplier relationships. Purchasing 109, 62-84.

[95] Morgan et al., (1990). Understanding the power and the rule of the thumb in sample size Determination. University of Wiscosin-La Crosse. 


\section{International Journal of Science and Research (IJSR) \\ ISSN (Online): 2319-7064}

Index Copernicus Value (2013): 6.14 | Impact Factor (2015): 6.391

[96] Mugenda, O. M. \& Mugenda, A. G. (2003). Research Methods: Quantitative and Qualitative Approaches: African Technology Studies Centre, Kampala.

[97] Katabaazi J.N, Kitutu F.E, et al,. (2010). Expiry of medicines in supply outlets in Uganda. SciELO Public Health Bull World Health Organ 2010; 88:154-158

[98] Krejcie, R. V., \& Morgan, D. W. (1970). Determining sample size for research activities. Educational and Psychological Measurement, 30, 607-610.

[99] National Drug Authority (2012). Essential Drug List.

[100]Neelam Sekhri (2006). Center for Global Development report on why demand forecasting is not working in the current environment. (CGD).

[101]Ntayi et al., (2007). Knowledge management and competitive advantage: The interactive effect of market orientation. Makerere business school Uganda.

[102]Ntayi, J.M., Gerrit, R., and Eyaa, S. (2008, 2009), supply chain Swiftness in a Developing Country: The Case of Uganda Small and Medium Sized Enterprises, E-Journal of Business and Economic Issues, Vol. IV, No. I.

[103]Nunnally, J.C., 1978. Psychometric Theory. McGrawHill, New York

[104]Oluka el al (2010), Tackling supply chain bottlenecks of essential Drugs: a case of Uganda local Government Health units

[105] Onwuegbuzie, A. J. \& Combs, J. P. (2007). Data Analysis in Mixed Research. A Primer. International of Education 3(1): E13.

[106] Onwuegbuzie, A. J., \& Johnson, R. B. (2006). The validity issue in mixed research. Research in the Schools, 13(1), 48-63.

[107] Solis, Adriano 2001. The importance of information flow in supply chain management. .<http://www.utminers.utep.edu/solis

[108]Padmanabhan, V., \& Whang S, Lee H.L . (1997). The bullwhip effect in supply chains, Sloan Management Review, Spring: 93-102

[109]Ranganathan, C., J. S. Dhaliwal, et al. (2004). "Assimilation and Diffusion of Web Technologies in Supply-Chain Management: An Examination of Key Drivers and Performance Impacts." International Journal of Electronic Commerce 9(1): 127-161

[110]Rupple C (2004). — information systems perspective of supply chain tool compatibility: the roles of technology fit and relationships", Bus. Process. Management. J., 10(3): 311-324.

[111]Samaddar S, Nargundkar S, Dalcy M (2006). Interorganizational information sharing: the role of supply network configuration and partner goal congruence. European. J. Operational. Res., 174: 744-765.

[112] Shiu Kong Lau, Jason 2007. Information sharing in supply chains. Improving the performance of collaboration. Die Deutsche Bibliothek

[113] Simchi-Levi, David \& Kaminsky, Philip \& SimchiLevi, Edith ( 2003). Designing and Managing The Supply Chain. Concepts, Strategies \& Case studies. McGraw-Hill Higher Education

[114] Singh J (1996). The importance of information flow within the supply chain. Logistic. Information Management, 9(4): 28-30.
[115]Skjott-Larsen, Tage \& Schary, Philip B. (2007). Managing the Global Supply Chain. Denmark: Copenhagen Business School Press. Third Edition.

[116]SmartOps (2005): Inventory Optimization Software Supply Chain Planning Solutions. SmartOps Corporation. <http://www.smartops.com/>.

[117]Sun S, Yen J (2005). Information supply chain: A unified framework for information-sharing”, ISI. LNCS 3495, pp. 422-428.

[118]SURE (2012). Securing Ugandans' Right to Essential Medicines at District level Sveiby, K.E, (1997). The new organization wealth. Beret Koehler Publishers Inc. San Franscisco CA

[119] Sweet, S. A. \& Grace-Martin, A. (2011). Data Analysis with SPSS: A First Course in Applied Statistics. Unpublished Text, Cornell University

[120]Towill D.R, Evans G.N., \& Cheema P. (1997) Analysis and design of an adaptive minimum reasonable inventory control system. Retrieved http://www.informaworld.com/smpp/content content= a1713842805\&db=all

[121] Truxillo, Catherine. (2003). Multivariate Statistical Methods: Practical Research Applications Course Notes. Cary, N.C.: SAS Institute.

[122]Weill, P. (1992). "The Relationship Between Investment in Information Technology and Firm Performance: A Study of the Valve Manufacturing Sector." Information Systems Research 3(4): 307-333.

[123]WHO (2005) Prescription for healthy development: increasing access to Medicines. Sterling, VA: Earthscan, (A Report of the Task Force on HIV/AIDS, Malaria, TB, and Access to Essential Medicines, Working Group on Access to Essential Medicines.)

[124]World Health Organization.(2004) Medicines strategy: countries at the core 2004-2007. http://whqlibdoc.who.int/hq/2004/WHO_EDM_2004.5. pdf (accessed 26th Sept 2014).

[125] Wisner JD, Leong GK, Tan KC (2005). Principles of Supply Chain Management. Thomson South-Western, Mason, Ohio, U.S.

[126]Whipple, J.M., R. Frankel and P.J. Daugherty. (2002), "Information Support for Alliances: Performance Implications", Journal of Business Logistics, (23:2), pp.67-81.

[127]Yang, Z., Wang, X. \& Su, C. (2006). A review of Research Methodologies in International Business. International Business review: 15:601-617. 